\title{
Pengaruh Pemberian Jus Umbi Bit Terhadap Kenaikan Kadar Haemoglobin Pada Ibu Hamil Dengan Anemia Di BPM Miftah Wahyudi Kec. Jatijajar Depok Tahun 2019
}

\author{
Triana Indrayani*, Risza choirunissa, Marlin Herlina Tambunan \\ Fakultas Ilmu Kesehatan, Universitas Nasional, Jakarta, Indonesia \\ Corresponding author: Triana Indrayani (trianaindrayani@civitas.unas.ac.id) \\ Received: Mei, 20 2020; Accepted: June, 28 2020; Published: September, 12020
}

\begin{abstract}
ABSTRAK
Berdasarkan hasil data di peroleh, 31\% ibu hamil memiliki Hb dibawah 11\% di BPM Miftah Wahyudi. Penulis tertarik meninjau pengaruh pemberian Jus Umbi Bit terhadap kenaikan kadar haemoglobin pada ibu hamil dengan anemia.

Tujuan penelitian ini untuk mengetahui pengaruh pemberian jus umbi bit terhadap kenaikan kadar haemoglobin pada ibu hamil dengan anemia di BPM Miftah Wahyudi.

Dalam penelitian ini menggunakan quasy experimental dengan rancangan two group pretestposttest with contol group design.

Diperoleh nilai selisih mean pretest pada kelompok intervensi dan tidak intervensi $-0,08$. Diperoleh nilai selisih mean pretest dan posttest pada kelompok intervensi 2,55. Pada pretest dan posttest kelompok tidak intervensi 0,03. Pada posttest kelompok intervensi dan tidak intervensi didapat selisih nilai mean 0,71. Kelompok tidak intervensi dan intervensi posttest menunjukkan bahwa nilai $p$ value 0,00 . Kelompok intervensi pretest dan posttest nilai $p$ value 0,00 . Kelompok tidak intervensi pretest dan posttest nilai $p$ value 0,85 .

Ada pengaruh pemberian jus umbi bit terhadap kenaikan kadar haemoglobin pada ibu hamil dengan anemia. Saran untuk tempat peneliti diharapkan menyelenggarakan penyuluhan atau pendidikan kesehatan tentang pemanfaatan umbi bit untuk pemenuhan kebutuhan zat besi.
\end{abstract}

Kata Kunci: Haemoglobin, Jus Umbi Bit, Ibu Hamil

This is an open-acces article distributed under the terms of the Creative Commons Attribution-ShareAlike 4.0 International License.

\section{PENDAHULUAN}

Menurut World Health Organization (WHO, 2017) melaporkan bahwa prevalensi ibuibu hamil di seluruh dunia yang mengalami anemia sebesar 41,8\%. Dari data tahun 2018 jumlah ibu hamil yang mengalami anemia tertinggi berada pada ibu hami berusia 15-24 tahun sebanyak 84,6\% (Riskesdas, 2018). Prevalensi angka kejadian anemia pada ibu hamil di Provinsi Jawa Barat sebesar 51,7\%. (Dinkes Prov. Jabar, 2017). Prevalensi angka kejadian anemia pada ibu hamil di Kota Depok sebanyak 3, 87\% (Profil Kesehatan Kota Depok, 2017).

Berdasarkan hasil olah data yang di peroleh dari, terdapat sekitar $31 \%$ ibu hamil memiliki kadar $\mathrm{Hb}$ dibawah $11 \mathrm{~g} \%$ di wilayah kerja UPT Puskesmas Jatijajar. 
Berdasarkan hasil olah data yang di peroleh dari BPM Miftah Wahyudi, terdapat sekitar 31\% (32 ibu hamil) ibu memiliki kadar Hb dibawah $11 \mathrm{~g} \%$ dari 103 ibu hamil yang memeriksakan kehamilannya di BPM Miftah Wahyudi.

\section{METODE}

Penelitian adalah suatu bentuk rancangan yang digunakan dalam melakukan prosedur penelitian. Penelitian ini merupakan penelitian quasy experimental dengan rancangan PretestPosttest Non Equivalent Kontrol Group Design yaitu penelitian yang dilakukan pada dua atau lebih kelompok yang diukur sebelum dan setelah perlakuan. Kelompok Intervensi mendapatkan pemberian jus umbi bit 1 hari sekali yaitu pada malam hari selama 14 hari dan kelompok tidak Intervensi tidak mendapatkan pemberian jus Umbi bit.

Populasi dari penelitian ini adalah seluruh ibu hamil yang mengalami anemia dan pemeriksaan kehamilannya di BPM Miftah Wahyudi, yaitu sebanyak 30 orang. Sampel dari penelitian ini ialah sebanyak 15 orang kelompok intervensi dan 15 orang kelompok tidak intervensi.

Peneliti melakukan intervensi dengan memberikan jus umbi bit terhadap kelompok intervensi agar dikonsumsi setiap hari, malam sebelum tidur sebanyak $500 \mathrm{ml} / \mathrm{hari} /$ orang dan diberi tablet Fe selama 14 hari untuk mengetahui adakah kenaikan haemoglobin, sedangkan kelompok kontrol tidak mengkonsumsi jus umbi bit dan tetap diberi tablet Fe. Kemudian dilakukan pretest berupa cek $\mathrm{Hb}$ pada kedua kelompok tersebut. Setelah 14 hari dilakukan posttest berupa cek $\mathrm{Hb}$ pada kedua kelompok tersebut. Pengukuran menggunakan Haemoglobin Testing System Quik-Check (Easy Touch).

\section{HASIL}

\section{Analisis Univariat}

Tabel 4.1 Distribusi Frekuensi Kadar Haemoglobin pada Kelompok Intervensi Ibu Hamil dengan Anemia Sebelum dan Setelah pemberian Jus Umbi Bit

\begin{tabular}{lcccccccc}
\hline & \multicolumn{3}{c}{ Kelompok Intervensi } & \multicolumn{3}{c}{ Kelompok Kontrol } \\
\cline { 2 - 9 } $\begin{array}{c}\text { Kadar } \\
\text { Haemoglobin }\end{array}$ & $\mathbf{N}$ & $\%$ & $\mathbf{N}$ & $\%$ & $\mathbf{N}$ & $\%$ & $\mathbf{N}$ & $\%$ \\
& & & & & & & & Post-Test \\
\cline { 2 - 9 } & 0 & 0 & 15 & 100 & 0 & 0 & 0 & 100 \\
\hline Normal & 14 & 93 & 0 & 0 & 14 & 93 & 15 & 0 \\
Ringan & 1 & 7 & 0 & 0 & 1 & 7 & 0 & 0 \\
Sedang & 15 & 100 & 15 & 100 & 15 & 100 & 15 & 100 \\
\hline \multicolumn{1}{c}{ Total } & & & & & & & & \\
\hline
\end{tabular}

Berdasarkan tabel 4.1 menunjukkan bahwa kelompok intervensi pada pre-test responden yang memiliki kadar haemoglobin tertinggi ada pada kategori Ringan yaitu sebanyak 14 responden (93\%), sedangkan pada post-test semua responden memiliki kadar haemoglobin $>11$ gr\% yaitu sebanyak $15(100 \%)$ orang. Dan Kelompok Kontrol pada pre-test responden yang memiliki kadar hb tertinggi ada pada kategori Ringan yaitu sebanyak 14 responden $(93 \%)$, sedangkan pada post test responden memiliki haemoglobin terbanyak ada pada kategori ringan yaitu sebanyak 15 responden (100\%). 


\section{Uji Normalitas}

Tabel 4.2 Uji Normalitas Kadar Haemoglobin Pre-test dan Post-test Pada Kelompok Kontrol pada Ibu Hamil dengan Anemia

\begin{tabular}{ccccc}
\hline \multirow{2}{*}{ Variabel } & \multicolumn{2}{c}{ Intervensi } & \multicolumn{2}{c}{ Kontrol } \\
\cline { 2 - 5 } & $\begin{array}{c}\text { Pre- } \\
\text { test }\end{array}$ & $\begin{array}{c}\text { Post- } \\
\text { test }\end{array}$ & $\begin{array}{c}\text { Pre- } \\
\text { test }\end{array}$ & $\begin{array}{c}\text { Post- } \\
\text { test }\end{array}$ \\
\hline $\begin{array}{c}\text { Kadar } \\
\text { Haemoglobin }\end{array}$ & 0,27 & 0,73 & 0,93 & 0,23
\end{tabular}

Berdasarkan tabel 4.2 menunjukan bahwa hasil analisis uji normalitas menggunakan Shapiro Wilk. Pada kelompok intervensi pre-test didapatkan 0.27 dan post-test didapatkan 0.73 . Hasil uji tersebut menunjukan nilai $>0.05$, yang artinya data berdistribusi normal. Sedangkan pada Kelompok Kontrol pre-test didapatkan 0.93 dan post-test didapatkan 0.23. Hasil uji tersebut juga memiliki nilai $>0.05$, Artinya data pada Kontrolber distribusi normal. Berdasarkan hasil tersebut, dengan demikian variabel kadar haemoglobin disimpulkan berdistribusi normal

\section{Analisa Bivariat}

Tabel 4.3 Pengaruh Pemberian Jus Umbi Bit terhadap Kadar Haemoglobin Ibu Hamil dengan Anemi

\begin{tabular}{ccccc}
\hline \multirow{2}{*}{ Kelompok } & \multicolumn{4}{c}{ Intervensi } \\
\cline { 2 - 3 } & Mean & SD & $\begin{array}{c}\text { SE } \\
\text { Mean }\end{array}$ & $\begin{array}{c}\boldsymbol{P} \\
\text { Value }\end{array}$ \\
\hline Pretest & 9,80 & 0,58 & 0,14 & 0,00 \\
Posttest & 12,35 & 0,71 & 0,18 & \\
\hline
\end{tabular}

Berdasarkan tabel 4.3 menunjukan hasil bahwa nilai mean pretest sebesar 9,80 dan posttest sebesar 12,35 sehingga dapat dilihat ada peningkatan nilai mean dari pretest dan posttest dengan selisih 2,55. Hasil $p$ value 0,00 yang artinya nilai $p$ value $<0,05$, maka Ho ditolak. Sehingga jus umbi bit memiliki pengaruh terhadap kenaikan kadar haemoglobin.

Tabel 4.4 Pengaruh Pemberian Jus Umbi Bit terhadap Kadar Haemoglobin Ibu Hamil dengan Anemia

\begin{tabular}{ccccc}
\hline & \multicolumn{4}{c}{ Kontrol } \\
\cline { 2 - 5 } Kelompok & Mean & SD & $\begin{array}{c}\text { SE } \\
\text { Mean }\end{array}$ & $\begin{array}{c}\boldsymbol{P} \\
\text { Value }\end{array}$ \\
\hline Pretest & 9,88 & 0,60 & 0,15 & 0,85 \\
Posttest & 9,85 & 0,50 & 0,12 & \\
\hline
\end{tabular}

Hasil pada tabel 4.4 menunjukan bahwa nilai pada kelompok yang kontrol didapat nilai mean pretest sebesar 9,88 dan posttest sebesar 9,85 sehingga didapat selisih 0,03 antara pretest dan posttest. Nilai $p$ value sebesar 0,85 yang artinya $p$ value $>0,05$ maka Ho diterima sehingga jus umbi bit tidak memiliki pengaruh terhadap kenaikan kadar haemoglobin. 
Tabel 4.5 Pengaruh Pemberian Jus Umbi Bit terhadap Kadar Haemoglobin Ibu Hamil dengan Anemia Setelah pemberian Jus Umbi Bit

\begin{tabular}{ccccc}
\hline \multirow{2}{*}{ Kelompok } & \multicolumn{4}{c}{ Intervensi \& Kontrol } \\
\cline { 2 - 3 } & Mean & SD & SE & $\boldsymbol{P}$ \\
Mean & Value \\
\hline Posttest & 12,35 & 0,71 & 0,18 & 0,00 \\
Posttest & 9,82 & 0,53 & 0,13 & \\
\hline
\end{tabular}

Berdasarkan tabel 4.5 didapat hasil setelah diberi intervensi dan kontrol nilai mean pada kelompok intervensi sebesar 12,35 dan Kontrol sebesar 9,82 dengan perseberan data pada kelompok intervensi sebesar 0,71 dan kelompok kontrol sebesar 0,53 . Nilai $p$ value pada kedua kelompok didapat sebesar 0,00 , yang artinya $p$ value $<0,05$ maka Ho ditolak sehingga terdapat pengaruh antara pemberian jus umbi bit dan tidak diberikan jus umbi bit terhadap peningkatan kadar haemoglobin.

Tabel 4.6 Perbedaan Kadar Haemoglobin pada Kelompok Intervensi dan kontrol sebelum diberi Jus Umbi Bit Pada Ibu Hamil dengan Anemia

\section{Pre-test}

\begin{tabular}{ccccccc} 
Kelompok & $\mathbf{N}$ & Mean & $\begin{array}{c}\text { Selisih } \\
\text { Mean }\end{array}$ & $\begin{array}{c}\text { Std. } \\
\text { Deviation }\end{array}$ & SE & Value \\
\hline Intervensi & 15 & 9,8 & $-0,08$ & 0,58 & 0,14 & 0,00 \\
Kontrol & 15 & 9,88 & & 0,6 & 0,15 & \\
\hline
\end{tabular}

Berdasarkan tabel 4.6 menunjukan bahwa hasil analisis menggunakan uji paired t-test didapat hasil nilai mean intervensi sebesar 9,80 dan hasil mean tidak intervensi sebesar 9,88 sehingga didapat selisih mean sebesar -0,08. Sebaran data pada kelompok intervensi sebesar 0,58 dan kelompok kontrol sebesar 0,60 sehingga didapat selisih standar devisiasi sebesar 0,02 .

Tabel 4.7 Perbedaan Kadar Haemoglobin pada Kelompok Intervensi dan Kelompok Kontrol setelah diberi Jus Umbi Bit Pada Ibu Hamil dengan Anemia

$$
\text { Pre-test }
$$

\begin{tabular}{ccccccc} 
Kelompok & N & Mean & $\begin{array}{c}\text { Selisih } \\
\text { Mean }\end{array}$ & $\begin{array}{c}\text { Std. } \\
\text { Deviation }\end{array}$ & SE & $\begin{array}{c}\boldsymbol{P} \\
\text { Value }\end{array}$ \\
\hline Intervensi & 15 & 12,35 & 2,53 & 0,71 & 0,18 & 0,00 \\
Kontrol & 15 & 9,82 & & 0,53 & 0,13 & \\
\hline
\end{tabular}

Berdasarkan tabel 4.7 menunjukan bahwa hasil analisis menggunakan uji paired t-test didapat hasil nilai mean intervensi sebesar 12,35 dan hasil mean kontrol sebesar 9,82 sehingga didapat selisih mean sebesar 2,53. Sebaran data pada kelompok intervensi sebesar 0,71 dan Kontrol sebesar 0,53 sehingga didapat selisih standar devisiasi sebesar 0,18. 
PEMBAHASAN

Analisi Univariat

Distribusi frekuensi kadar haemoglobin pada kelompok intervensi dan Kontrol pada ibu hamil

Berdasarkan hasil penelitian ini menunjukkan bahwa kelompok intervensi pada pre-test responden yang memiliki kadar haemoglobin tertinggi ada pada kategori ringan $(9-10 \mathrm{gr} \%)$ yaitu sebanyak 14 responden (93\%), sedangkan pada post-test semua responden memiliki kadar haemoglobin normal >11gr\% yaitu sebanyak 15 (100\%) orang. Kontrol pada pre-test responden yang memiliki kadar hb tertinggi ada pada kategori ringan (9-10\%) yaitu sebanyak 14 responden (93\%), sedangkan pada post test responden memiliki haemoglobin terbanyak ada pada kategori ringan yaitu sebanyak 15 responden $(100 \%)$.

Hasil penelitian ini sejalan dengan penelitian yang dilakukan oleh Stephana, dkk (2015). Terjadi peningkatan rata-rata kadar haemoglobin ibu hamil dengan anemia sesudah diberikan jus Umbi bit (Posttest) pada kelompok eksperimen sedangkan kelompok kontrol tidak ada terjadi peningkatan rata-rata kadar haemoglobin (Posttest) tanpa diberikan jus Umbi bit. Dan sejalan pula dengan penelitian yang dilakukan oleh Dina Dewi Anggraini (2018)

\section{Analisa Bivariat \\ Perbedaan Kadar Haemoglobin pada Kelompok Intervensi dan Kontrol sebelum diberi Jus Umbi Bit Pada Ibu Hamil dengan Anemia}

Berdasarkan hasil penelitian menunjukkan bahwa hasil analisis menggunakan uji paired $t$-test pada kelompok intervensi dan kontrol sebelum pemberian jus Umbi bit diperoleh nilai selisih mean sebesar $-0,08$

Anemia pada kehamilan didefinisikan anemia karena kekurangan zat besi. anemia pada ibu hamil dapat diklasifikasikan menjadi 4, yaitu: tidak Anemia : Hb $11 \mathrm{~g} \mathrm{r} \%$, Anemia ringan : Hb $9-10$ gr \%, Anemia sedang : Hb $7-8$ gr \%, Anemia berat : $\mathrm{Hb}<7$ gr \% (Manuaba, 2014). selama kehamilan, terjadi hyperplasia erythroid dari sum-sum tulang, dan meningkatkan massa RBC. Namun, peningkatan yang tidak proporsinal dalam hasil volume plasma menyebabkan hemodilusi (hydremia kehamilan). (Atikah proverawati, 2011).

Hasil penelitian ini sejalan dengan penelitian yang dilakukan oleh Dwi Amalia Rahmadani (2018) pada kelompok kontrol pre-test dan post-test didapatkan nilai $p$ value 0,001 $<0,05$ yang artinya ada perbedaan yang signifikan. Dan sejalan pula dengan penelitian yang dilakukan Wiulin Setiawati dan Siti Nurul (2018) didapat nilai p value 0,002<0,005.

\section{Kadar Haemoglobin pada Kelompok Intervensi dan Kelompok Kontrol setelah diberi Jus Umbi Bit Pada Ibu Hamil dengan Anemia}

Berdasarkan hasil analisis menunjukkan bahwa hasil analisis menggunakan uji paired sampel t-test pada kelompok intervensi dan kontrol setelah pemberian jus Umbi bit diperoleh nilai selisih mean sebesar 2,53.

Hasil penelitian ini sejalan dengan penelitian yang dilakukan oleh Dwi Amalia Rahmadani (2018) dan Wiulin Setiawati dan Siti Nurul (2018), Archives of Pharmaceutical Sciences Ain Shams University 2018.

\section{Pengaruh Pemberian Jus Umbi Bit terhadap Kadar Haemoglobin Ibu Hamil dengan Anemia Kelompok Intervensi}

Berdasarkan hasil analisis menunjukkan bahwa nilai $p$ value 0,000 . Karena nilai $p$ value $0,00<0,05$, maka Ho ditolak. Dengan kata lain jus Umbi bit memiliki pengaruh terhadap kenaikan kadar haemoglobin.

Kandungan zat besi Umbi bit memiliki kandungan asam folat dan zat besi yang cukup tinggi, yang mengaktifkan kembali dan meregenerasi sel darah merah serta menyuplai oksigen 
yang berguna bagi kesehatan sel-sel merah. Umbi bit juga mengandung vitamin $\mathrm{C}$ yang akan memudahkan tubuh menyerap zat besi, yang artinya jika zat besi dapat diserap dengan baik pembentukan sel darah merah baru juga akan terjadi dengan baik dan lancar. (Novita,2018).

Hasil penelitian ini sejalan dengan penelitian yang dilakukan oleh Dwi Amalia Rahmadani (2018) pada kelompok kontrol pretest dan posttest didapatkan nilai $p$ value $0,001<0,05$ yang artinya ada perbedaan yang signifikan. Dan sejalan pula dengan penelitian yang dilakukan Wiulin Setiawati dan Siti Nurul (2018) didapat nilai $p$ value 0,002<0,005, IOSR Journal of Nursing and Health Science.

\section{Pengaruh Pemberian Jus Umbi Bit terhadap Kadar Haemoglobin Ibu Hamil dengan Anemia}

Berdasarkan hasil analisis menunjukkan bahwa nilai $p$ value 0,00 . Karena nilai $p$ value 0,85>0,05, maka Ho diterima. Dengan kata lain jus Umbi bit tidak memiliki pengaruh terhadap kenaikan kadar haemoglobin.

Umbi bit mengandung sebagian besar vitamin A dan vitamin C, kalsium zat besi, fosfor, protein dan karbohidrat. Umbi bit juga tinggi folat dan betasianin (Mulyani, 2015).

Hasil penelitian ini sejalan dengan penelitian yang dilakukan oleh Stephana, dkk (2015) dan yang dilakukan oleh Dina Dewi Anggraini (2018), IOSR Journal of Nursing and Health Science 2013.

\section{Pengaruh Pemberian Jus Umbi Bit terhadap Kadar Haemoglobin Ibu Hamil dengan Anemia Setelah pemberian Jus Umbi bit}

Berdasarkan hasil analisis menunjukkan bahwa nilai $p$ value $0,00<0,05$, maka Ho ditolak. Dengan kata lain jus Umbi bit memiliki pengaruh terhadap kenaikan kadar haemoglobin

Hasil penelitian ini sejalan dengan penelitian yang dilakukan oleh Dwi Amalia Rahmadani (2018) pada kelompok kontrol pre-test dan post-test didapatkan nilai $p$ value 0,001 $<0,05$ yang artinya ada perbedaan yang signifikan. Dan sejalan pula dengan penelitian yang dilakukan Wiulin Setiawati dan Siti Nurul (2018) didapat nilai p value 0,002<0,005

\section{KESIMPULAN}

Berdasarkan hasil penelitian tentang pengaruh pemberian jus umbi bit terhadap kenaikan kadar hemoglobin pada ibu hamil dengan anemia di BPM Miftah Wahyudi tahun 2019, maka dapat disimpulkan bahwa :

1. Hasil analisis pada kelompok intervensi $p$ value 0,00 yang artinya terdapat pengaruh yang signifikan antara kelompok intervensi dan kontrol sebelum diberikan jus umbi bit pada ibu hamil dengan anemia di BPM Miftah Wahyudi tahun 2019.

2. Pada kelompok kontrol $p$ value 0,85 yang arinya tidak terdapat perbedaan yang signifikan antara kelompok intervensi dan kontrol setelah diberikan jus umbi bit pada ibu hamil dengan anemia di BPM Miftah Wahyudi tahun 2019.

\section{DAFTAR PUSTAKA}

Arthathi Eka Suryandan. 2015. Perbandingan Kenaikan Kadar Hb Pada Ibu Hamil Yang diberi Fe Dengan Fe dan Buah Bit di Wilayah Kerja Puskesmas Purwokerto Selatan. Jurnal Kebidanan. Vol VII, No.1

Dinas Kesehatan Provinsi Jawa Barat. 2017. Profil Kesehatan 2017

Dinas Kesehatan Kota Depok 2017. Profil Kesehatan 2017

Dr. N. Gayathri Priya. 2013. Beet root juice on haemoglobin among adolescent girls. IOSR Journal of Nursing and Health Science. Volume 2 
Favour. Nyoh Beshel. 2018.The Ethanolic Extract of Beetroot (Beta Vulgaris) Ameliorates Some Red Cell Parameters In Phenylhydrazine-Induced Anaemic Rats. IOSR Journal of Nursing and Health Science (IOSR-JNHS). Volume 7

Guyton A.C., Hall J.E.2012. Buku ajar fisiologi kedokteran Edisi 11. Jakarta: Penerbit Buku Kedokteran EGC.H

Hardani, S. 2013. Pembuatan Es Krim Probiotik dari Buah Bit (Beta Vulgaris L) Sebagai Pewarna Alami Dengan Ice Cream Maker. Skripsi. Diakses Pada Tanggal 4 Februari 2016. http://eprints.undip.ac.id/44371/

Kementerian Kesehatan Republik Indonesia 2015. Menuju Persalinan yang Aman dan Selamat agar Ibu Sehat Bayi Sehat. DEPKES

Kartika Ikawati. 2018. Pengaruh Buah Bit (Beta Vulgaris) Terhapah Indek Eritrosit Pada Remaja Putri Dengan Anemia. Journal Of Nursing And Publik Health. Vol 6 No. 2

Lingga, L. 2010. Cerdas Memilih Sayuran. Jakarta: Agro Media Pustaka

Manuaba, IBG. (2014). Ilmu Kebidanan Penyakit Kandungan dan Keluarga Berencana untuk Pendidikan Bidan Jakarta : EGC

Masuti, R. Y. Cai. H Corke. 2010. Identifikasi Pigmen Betasianin Pada Beberapa Jenis Inflorence Celosia. Seminar Nasional Biologi. Diakses pada tanggal 4 Februari 2016. http://dokumen.tips/documents/58-identifikasi-pigmen-betasianin-pada beberapa-jenis-infloresence-celosia.html

Muazizah. 2011. Hubungan Antara Kadar Hemoglobin Ibu Hamil dengan Berat Bayi Lahir di RS Permata Bunda Kabupaten Grobogan. Semarang. Skripsi. Semarang: Universitas Muhammadiyah Semarang

Mulyani, S. 2015. Aktivitas Antimikroba Ekstrak Etanol Umbi Bit (Beta vulgaris), Ekstrak Kelopak Bunga Rosella (Hibiscus sabdariffa) dan produk herbal. Skripsi.http://repository.ump.ac.id/122/3/SITI\%20MULYANI\%20BAB\%20II.PDF

Notoatmodjo, S. 2012. Metodelogi Kebidanan. Jakarta : Rineka Cipta

Pratami, E. (2016). Evidence Based dalam Kebidanan: Kehamilan, persalinan, dan nifas. Jakarta : EGC

Proverawati, A. 2011. Anemia dan Anemia Kehamilan. Yogyakarta: Nuha Medika.

Retinol amog pregnant women: Implications for pregnancy outcome in southwest Nigeria. Pak. J. Nutr.2008; 7(3):480-484

Riset Kesehatan Dasar. 2018. Hasil Utama Riskesda 2018. Jakarta: RISKESDAS

Roosleyn \& Intan Parrulin T. 2016 Strategi dalam Penanggulangan Pencegahan Anemia pada Kehamilan. Binawan. Jurnal Ilmiah Widya. 2016. 3 (3-7). ISSN: 2337-6686. Sekolah Tinggi Ilmu Kesehatan Binawan. Diakses dari related:https://ejournal.jurwidyakop3.com/index.php/jurnal

Sarwono, P. 2014. Ilmu Kebidanan. Jakarta: PT. Bina Pustaka Sarwono Prawirohardjo

Sembiring. 2010. Hubungan Anemia Dalam Kehamilan Dengan Kejadian Perdarahan Post Partum di RSUP H. Adam Malik Medan. Diakses dari http://www.com.JurnalPenelitian.pdf

Sharma J B, Shankar, Meenakshi. 2010. Anemia in Pregnancy. Journal of International Medical Sciences Academy. 2010 Disember: 33(4): 235-66

Shahenda M. Elaby. 2018. The Anti-Anemic Effect Of Dried Beet Green In Phenylhydrazine Treated Rats. Archives Of Pharmaceutical Science Ain Shams University. Vol.2, 54-69

Sukrat B. And Sirichotiyakul S. 2006. The prevalence and caudes of anemia during pregnancy in Maharaj Nakorn Chiang Mai Hospital. J. Med. Assoc. Thai 89 (Suppl 4): S142146

Wenda Stephana. 2016. Efektivitas Pemberian Jus Buah Bit Terhadap Kadar Haemoglobin Ibu Hamil Dengan Anemia. Universitas Riau 